\title{
Development of simple sequence repeat (SSR) markers and genetic diversity analysis in black- wood (Acacia melanoxylon) clones in china
}

\author{
Chunjie Fan, Qianyu Liu, Bingshan Zeng*, Zhenfei Qiu, Changpin Zhou, Kaoke Chen, \\ Guangsheng Guo
}

Research Institute of Tropical Forestry, Chinese Academy of Forestry, Guangzhou 510520, People's Republic of China

* Corresponding author: B.S.Zeng, Phone: +86 2087032851, E-mail: b.s.zeng@vip.tom.com

\begin{abstract}
Understanding the genetic diversity of Acacia melanoxylon is very important in species selection and improvement. The present study aimed to identify microsatellite markers and determine the genetic diversity of 45 preferred clones selected from 9 Chinese districts. Seventy-six simple sequence repeat (SSR) markers developed for other Acacia species were screened. Seventeen SSR markers showed polymorphic patterns and amplified 134 alleles. Polymorphism information content (PIC) values ranged from 0.044 to 0.911 . The average allele number per locus ranged between 2 and 18, averaging 8.06. Nine SSR markers were highly informative, with PIC values above 0.60 . These findings demonstrated that SSR markers could be used to differentiate $A$. melanoxylon genotypes. Cluster analysis using UPGMA separated the 45 clones into 3 distinct groups at a similarity coefficient of 0.72 . The clone groups identified in this study would be useful in developing intraspecific hybrids to exploit hybrid vigor as well as for commercial cultivation and genetic base broadening. The DNA fingerprints obtained for each clone could be used for biodiversity conservation.
\end{abstract}

Keywords: Acacia melanoxylon, SSR, genetic diversity, polymorphism information content

\section{Introduction}

Australian blackwood (Acacia melanoxylon) is one of the most widely distributed trees native to eastern Australia, with highquality and appearance-grade timber (Cowan and Maslin 2001). Blackwood timber is used to manufacture high-quality furniture, flooring, and musical instruments. Owing to its high timber value, New Zealand, South Africa, China, Chile and Vietnam have established exotic plantations (Bradbury et al. 2010, Pinkard and Beadle 2002). Since the late 1980s, China has developed a series of provenance trials of the species (Zhang F et al. 2002). Currently, A. melanoxylon is grown in Guangdong, Guangxi, Fujian and Jiangxi provinces in pure stands. In previous studies, we selected 45 clones from 9 sampling sites mainly distributed in Guangdong, Guangxi and Fujian provinces. However, proper records of some clones originating from progeny and provenance trials may not have been kept during breeding, and therefore could not be distinguished clearly. Hence, developing molecular markers of selected blackwood clones is important in analyzing genetic variation and diversity. Meanwhile, this would open opportunities to further improve the efficiency of breeding programs of blackwood, especially in developing clonal breeding programs using marker-assisted selection, and broaden the genetic base of breeding populations.

More recently, genetic variation in the genus Acacia, including Acacia mangium Willd. (Butcher et al. 2000, Butcher and Moran 2000, Isoda and Watanabe 2006), A. auriculiformis (Nagashree et al. 2015, Yuskianti et al. 2011), A. mangium $\times$ A. auriculiformis ( $\mathrm{Ng}$ et al. 2005), A. auriculiformis $\times$ A. mangium, $A$. auriculiformis, A. crassicarpa and A. peregrinalis (Aggarwal et al. 2011, Wong et al. 2012), A. koa (Gustafson et al. 2008) and $A$. pennata (Gao et al. 2012) has been assessed. In A. melanoxylon, inter sequence repeat (ISSR) and CDNA-amplified fragment length polymorphism (CDNA-AFLP) markers have been developed (HU et al. 2008, Wei 2013). However, microsatellite 
markers, which are informative in population genetics because of high polymorphisms have not been applied in A. melanoxylon. Simple sequence repeat (SSR) marker development, as a powerful molecular approach, is widely used in establishing genetic relationships, genetic diversity assessment, and germplasm characterization in plants (Gao et al. 2012, Kato et al. 2014, Selkoe and Toonen 2006). SSR could complement phenotypic data with a genotypic assessment of diversity, and SSR genetic relationship analysis could help avoid closely related parents to ensure genetic variation for continued progress (Gopal and Oyama 2005). Hence, microsatellite markers explored in Acacia were selected for genetic diversity and structure determination of $45 \mathrm{~A}$. melanoxylon clones obtained from 9 sampling sites in Guangdong and Guangxi provinces of China in previous studies. Meanwhile, the development of microsatellite markers could be further used for linkage mapping, which in turn would help identify quantitative trait loci for marker assisted selection in blackwood.

\section{Material and Methods}

\section{Sample collection}

Leaves of 45 A. melanoxylon clones obtained from previously selected superior clones in Guangdong and Fujian provinces were used in this study. The detailed list is shown in Table 1; provenance and family records were described previously (Zhang et al. 2004, Zhang F et al. 2002).

Table 1

Forty-five blackwood clones used for SSR amplification analyses, with corresponding sources

\begin{tabular}{|c|c|c|}
\hline Clone & Source & $\begin{array}{l}\text { Provenance/ } \\
\text { Family }\end{array}$ \\
\hline CL01, CL02 & $\begin{array}{l}\text { Conghua, Gu- } \\
\text { angdong }\end{array}$ & $4 p$ \\
\hline DL02, DL03, DL04 & $\begin{array}{l}\text { Dongguan, } \\
\text { Guangdong }\end{array}$ & $20 f$ \\
\hline GB01, GB02, GF02, GF03, GF04 & $\begin{array}{l}\text { Gaofeng, Gu- } \\
\text { angxi }\end{array}$ & unknown \\
\hline $\begin{array}{c}\text { GL01, GL02, GL03, GL04, GL07, GL09, } \\
\text { GL10, GL12, GL13 }\end{array}$ & $\begin{array}{l}\text { Taishan, } \\
\text { Guangdong }\end{array}$ & $35 p$ \\
\hline HL01, HL02, HL04, HL05, HL06 & $\begin{array}{l}\text { Shixing, } \\
\text { Guangdong }\end{array}$ & $5 p$ \\
\hline LL02, LL03, LL04, LL05, LL06 & $\begin{array}{l}\text { Longdong, } \\
\text { Guangdong }\end{array}$ & $6 p$ \\
\hline SL01, SL02 & $\begin{array}{l}\text { Zengcheng, } \\
\text { Guangdong }\end{array}$ & $35 p$ \\
\hline TL01, TL03 & $\begin{array}{l}\text { Huadou, } \\
\text { Guangdong }\end{array}$ & $6 p$ \\
\hline $\begin{array}{l}\text { VS01, VS02, VS03, VS04, VS05, VT01, } \\
\text { VT02, VT03, VT04, VT05, VX01, VX02 }\end{array}$ & $\begin{array}{l}\text { Weihua, } \\
\text { Guangdong }\end{array}$ & $1 p$ \\
\hline
\end{tabular}

DNA extraction, SSR primers and PCR amplification Genomic DNA was extracted from A. melanoxylon leaves with Plant DNA extraction Kit (Aidlab, Beijing, China) following the manufacturer's instructions. Purified DNA was quantified by $1 \%$ agarose gel electrophoresis. DNA amounts were further evaluated on a NanoDrop 2000 spectrophotometer (NanoDrop, Thermo Scientific). Samples with concentrations $>100 \mathrm{ng} \mathrm{L}^{-1}$ and A260/A280 between 1.6 and 1.8 were used for PCR amplification. A total of 76 SSR markers were used in amplification analyses of $A$. melanoxylon. These included 15 primers previously used in Acacia mangium $\times$ A. auriculiformis) $(\mathrm{Ng}$ et al. 2005), 33 employed in A. mangium (Butcher et al. 2000), 20 used in A. auriculiformis $\times$ A. mangium (Le et al. 2016), and 8 employed in Paraserianthes falcataria (Saito et al. 2014).

Primers showing a clear amplification product with a length ranging between 80 and 400 bp under optimal annealing temperature were selected for further analysis (Figure 1).

Figure 1

Amplification products separated by $2.5 \%$ agar electrophoresis of the 41 selected primers. Lane 1-41 represent various primers; M, DNA marker

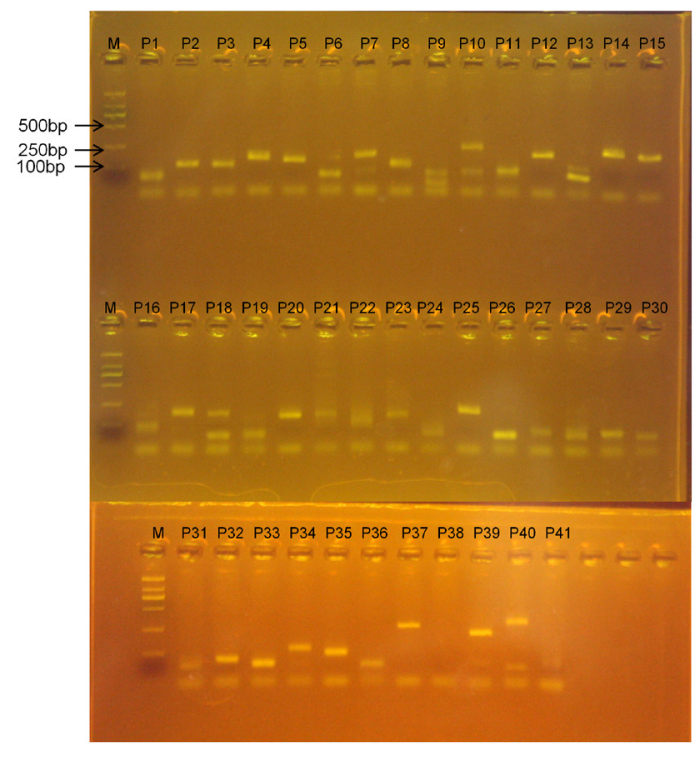

Then, SSR primers available from above mentioned studies were used in assessing the $45 \mathrm{~A}$. melanoxylon clones. For the latter system, each forward primer was $5^{\prime}$-tailed with the M13 forward consensus sequence (5'-CGTTGTAAAACGACGGC(AGT-3'). The M13-tagged forward primers were then employed in combination with a standard M13 primer 6-FAM-labeled at its $5^{\prime}$-end (Nicot et al. 2004). PCR reactions were performed in $20 \mu \mathrm{L}$ containing $1 \times P C R$ buffer, $1.5 \mathrm{mM} \mathrm{MgCl} 2,0.2 \mathrm{mM}$ dNTPs, 0.04 units Taq DNA polymerase (Takara), $0.2 \mu$ l forward primer, $0.8 \mu \mathrm{l}$ reverse primer, $0.8 \mu \mathrm{l}$ M13-labelled primer $(100 \mathrm{nM}$ of each of the primer pair), $1 \mu$ lemplate DNA, and sterile ddH2O. Amplification was performed on 96 a Veriti Applied Biosystems thermocycler programmed for initial denaturation $\left(94^{\circ} \mathrm{C}\right.$ for 5 min), 30 cycles $\left(94^{\circ} \mathrm{C}\right.$ for $30 \mathrm{~s}, 56^{\circ} \mathrm{C}$ for $45 \mathrm{~s}$, and $72^{\circ} \mathrm{C}$ for $\left.45 \mathrm{~s}\right), 8$ cycles $\left(94^{\circ} \mathrm{C}\right.$ for $30 \mathrm{~s}, 53^{\circ} \mathrm{C}$ for $45 \mathrm{~s}$ and $72^{\circ} \mathrm{C}$ for $\left.45 \mathrm{~s}\right)$, and a final extension $\left(72^{\circ} \mathrm{C}\right.$ for $\left.7 \mathrm{~min}\right)$. The PCR products were then added to HIDI formamide and LIZ-500 molecular standard, and subjected to capillary electrophoresis; the ABI3730 DNA genetic analyzer was used for fragment analysis. Allele calls were 
performed with the GENEMAPPER software v.3.7 (Applied Biosystems).

\section{Polymorphism analysis}

Data generated by the GENEMAPPER software were transferred to Excel, and analyzed for various genetic parameters such as allele number per locus, heterozygosity $(\mathrm{He})$, polymorphic information content (PIC) and genetic distance, using GenALEx (Peakall and Smouse 2006). Cluster analysis was employed to group the clones and generate a dendogram, with the NTSYSpc version 2.10e software (Rohlf 2005). The similarity coefficient was used to cluster clones based on molecular data according to the Unweighted Pair Group Method with Arithmetic Mean (UPGMA). A cluster plot of all 45 clones was constructed using SAHN (Sequential Agglomerative Hierarchic Non-overlapping clustering) and the Tree Plot procedures of the NTSYSpc version 2.10e software.

\section{Results and Discussion}

\section{Characteristics of SSR Markers}

Nine samples from 9 districts were used in screening 76 published SSR loci, including 68 and 8 from Acacia and P. falcataria, respectively. In agarose gel electrophoresis, 27 loci showed clear single band amplicons (Figure 1). Of these, 17 loci (22.37\%) were selected based on reliability and interpretable polymorphic amplification. These 17 SSR loci produced 134 alleles from the 45 A. melanoxylon clones. DNA amplification profiles of the 45 clones using the P12 marker are presented in Figure 2.

Figure 2

$2.5 \%$ agar electrophoresis showing PCR amplification of 45 clones of blackwood with the P12 marker. Lane 1-45 represent individual blackwood clones; M, DNA marker.

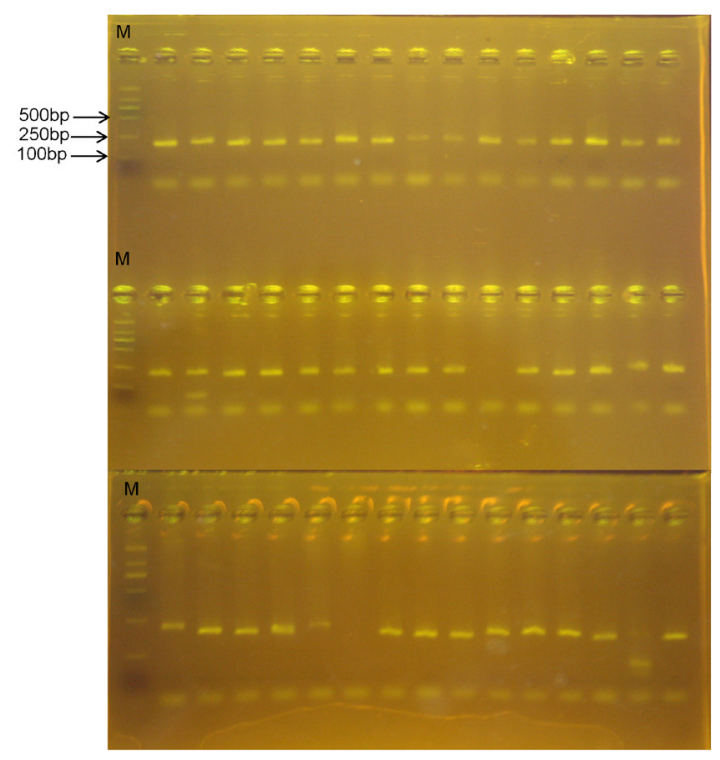

These results confirmed the transferability of SSR markers among A. melanoxylon, A. mangium, A. auriculiformis and $P$. falcataria. Similarly, six polymorphic microsatellite DNA markers from 82 published primers for Acacia were successfully used for A. pennata genetic diversity assessment by Gao et al. (2012). Interestingly, P17 (Am429) selected in this study was also amplified in A. pennata, suggesting that it can be used as a common microsatellite locus in Acacias. In previous studies, a high degree of collinearity between closely related species has been described, allowing cross-amplification of markers such as those reported in wheat, bean and Rosaceae species (Fan et al. 2013, Wang et al. 2015, Zhang et al. 2005). Transferability of A. mangium, A. mangium $\times$ A. auriculiformis and $P$. falcataria SSR markers to blackwood were reported to be $39.4 \%, 5.7 \%$ and $25.0 \%$, respectively, whereas $6.1 \%$ and $8.6 \%$ of $A$. mangium and $A$. mangium $\times A$. auriculiformis markers were achieved for A. auriculiformis, respectively (Gao et al. 2012).

Allele numbers across the 17 SSR loci ranged from 2 to 18 , averaging 8.06 alleles. PIC values estimated for all loci ranged from 0.911 to 0.044 , with an average of 0.609. Eight SSR loci (Primers 7, 8, 11, 14, 19, 21, 34, and 40) showed PIC values below 0.60 . PIC values usually characterize the markers for polymorphisms (Botstein et al. 1980, Grewal et al. 2014). This parameter could be influenced by various factors, including the nature of germplasm, number of SSR loci, and amounts of clones analyzed (Bantte and Prasanna 2003). In this study, we speculated that lower PIC values may be a result of closely related genotypes and provenance distribution. However, the remaining 9 SSR makers had a potential to detect differences among the $45 \mathrm{~A}$. melanoxylon clones assessed. Of these 9 markers, Primer 37 (AH76) amplified 18 alleles and showed the highest PIC value (0.911), indicating a high discrimination power (Table 2). Expected heterozygosity $(\mathrm{He})$ values, as a measure of allelic diversity at a given locus, varied from 0.706 to 0.067 , with an average of 0.434 .

\section{Genetic Relationships}

We found that the 17 microsatellite markers distinguished all 45 A. melanoxylon clones. Jaccard genetic similarity coefficients were between 0.65 and 0.99 . These findings indicated a relatively high genetic diversity among the selected $A$. melanoxylon clones. This is likely because the selected 45 clones were originated from multiple provenances. The dendogram constructed using the UPGMA clustering algorithm based on SSR data grouped the assessed blackwood clones into three major clusters at a similarity coefficient of 0.72 (Figure 3 ).

Of the 3 clusters formed, cluster I was the largest. The latter was further divided into four subgroups at a similarity coefficient of 0.80 . In the first subgroup, there were 2 clones (CL01 and CL02) selected from Conghua along with 4 (GL01, GL02, GL07 and GL13) from Taishan, 3 (LL02, LL04 and LL06) from Longdong, 2 (HL02 and HL04) from Shixing, and 3 (SL02, TL01 and VT03) from other districts. These clones selected from different sources were clustered into one group. Meanwhile, the highest genetic similarity coefficient in this subgroup was 0.99 between the CL01 and GL02 clones, suggesting that they 
Table 2

Primer sequences, annealing temperatures $(\mathrm{Tm})$ and sources of primers used for A. melanoxylon

\begin{tabular}{|c|c|c|c|c|c|}
\hline Primer & Sequence $\left(5^{\prime}-3^{\prime}\right)$ & $\operatorname{Tm}(o C)$ & Original code & Source species & Reference \\
\hline P4 & $\begin{array}{c}\text { TAGGCTAATGGTCATATTCCTAG } \\
\text { AGAGATAGGGGTACACACTAAAAAAC }\end{array}$ & 47 & Am041 & A. mangium & (Butcher et al. 2000) \\
\hline P7 & $\begin{array}{l}\text { CCATTCGAGCATCCTAAGAG } \\
\text { CGTATGGCTGAGCTACTTAATCA }\end{array}$ & 49 & Am341 & A. mangium & (Butcher et al. 2000) \\
\hline P8 & $\begin{array}{c}\text { CCTCATGTCCTTGAATGTCAC } \\
\text { GACTAACCCACAAGGAAGAGTTAC }\end{array}$ & 47 & Am352 & A. mangium & (Butcher et al. 2000) \\
\hline P10 & $\begin{array}{c}\text { AGACTTCATAAATAAGATGGAAGAGG } \\
\text { ATGCCAAATTTTCTTATTGGAG }\end{array}$ & 49 & Am384 & A. mangium & (Butcher et al. 2000) \\
\hline P11 & $\begin{array}{l}\text { TGATACAAGGGAAGACAGAGTGG } \\
\text { CCAACTCAAAACCTGACAACG }\end{array}$ & 54 & Am387 & A. mangium & (Butcher et al. 2000) \\
\hline P12 & $\begin{array}{l}\text { AATCCTTCCGAAAGTTATACATGG } \\
\text { GCACTTGTAAGTCGGAACTGC }\end{array}$ & 45 & Am389 & A. mangium & (Butcher et al. 2000) \\
\hline P14 & $\begin{array}{l}\text { CGGATGAGAAGTGGCATTAGG } \\
\text { GCCATCCAGAGTTGAAATTAGC }\end{array}$ & 49 & Am396 & A. mangium & (Butcher et al. 2000) \\
\hline P15 & $\begin{array}{c}\text { AAGCACTTCTAGATTGGCAGC } \\
\text { CAATAATCTAGAAACTACGGGACTTG }\end{array}$ & 45 & Am400 & A. mangium & (Butcher et al. 2000) \\
\hline P17 & $\begin{array}{c}\text { ССТTСТTСТСТСАТСТАССАААCС } \\
\text { СССАСАТСАТСАСТСАСААСТ }\end{array}$ & 48 & Am429 & A. mangium & (Butcher et al. 2000) \\
\hline P19 & $\begin{array}{l}\text { ATGGATCTTGTCCTTATCTTGA } \\
\text { GGGCCAATTTGAGTTTGGAA }\end{array}$ & 49 & Am436 & A. mangium & (Butcher et al. 2000) \\
\hline P20 & $\begin{array}{l}\text { CACTAATTGCTCACACATTCCA } \\
\text { ATTCATAGCCTCTCCCTTCAG }\end{array}$ & 45 & Am460 & A. mangium & (Butcher et al. 2000) \\
\hline P21 & $\begin{array}{l}\text { TGGGTATCACTTCCACCATT } \\
\text { AGGCTGCTTCTTTGTGCAGG }\end{array}$ & 47 & Am465 & A. mangium & (Butcher et al. 2000) \\
\hline $\mathrm{P} 25$ & $\begin{array}{l}\text { ATGAGTTTGACCCGACTTGA } \\
\text { TGCGTAACACGATTATCCCT }\end{array}$ & 49 & Am522 & A. mangium & (Butcher et al. 2000) \\
\hline P34 & $\begin{array}{l}\text { GATAGCTCATAGAAACACCATACC } \\
\text { GGCGAAGCTCTCTCTCTCTCTCTCTCT }\end{array}$ & 58 & AH56 & $\begin{array}{l}\text { A. mangium } \times \text { A. auricu- } \\
\text { liformis }\end{array}$ & (Ng et al. 2005) \\
\hline P37 & $\begin{array}{c}\text { GGGGAGGCTCTCTCTCTCTCTCTCTCT } \\
\text { GTGACCTGAGTTAGGAAGGAG }\end{array}$ & 48 & $\mathrm{AH} 76$ & $\begin{array}{l}\text { A. mangium } \times \text { A. auricu- } \\
\text { liformis }\end{array}$ & (Ng et al. 2005) \\
\hline P39 & $\begin{array}{l}\text { CTCTTGTACGTTTCTGAATGC } \\
\text { AGGCGTATACATTTACAAAT }\end{array}$ & 54 & $\mathrm{Pafa02}$ & $\begin{array}{l}\text { Paraserianthes falca- } \\
\text { taria }\end{array}$ & (Y Saito 2014) \\
\hline P40 & $\begin{array}{l}\text { AAGTCAGCTGTAAGTCATTG } \\
\text { GAGCAGAGAAAAAAGCTGATG }\end{array}$ & 54 & Pafa08 & P. falcataria & (Y Saito 2014) \\
\hline
\end{tabular}

originated from the same provenance/family or probably derived from the same clone. In previous reports, most districts were comprised only of two provenances, while in the Dongguang and Taishan progeny trials, 20 and 35 provenances were described, respectively (Zhang et al. 2004). Hence, part of the provenances might have originated from the same place in Australia.

In the first subgroup of cluster I, nearly all clones originated from Weihua and Dongguan, Guangdong, except GL04, HL06 and LL05. Furthermore, almost all VS, VT, and VX clones, apart from VS01, VS03 and VT03, were clustered in one subgroup with short genetic distances. These findings suggested that these clones could have originated from the same provenance, which explains the high level of similarity. This confirms that the VS, VT and VX clones, selected from Meizhou (Guangdong) should be regarded as originating from one provenance
(Zhang et al. 2004). In addition, HL06, DL04, VS02, VS05, VT02, VT04, VX01, VX02, VT05, and VT01, which showed good stem form with a single, straight, branch-free stem as well as excellent growth rates were clustered into one subgroup. This suggests that these clones may have originated from the same or similar provenance, explaining their high level of similarity. This provenance is therefore suitable for blackwood domestication in south China, and could further be used in multiple progeny trials, clonal and seedling seed orchards, and plantation development. The highest similarity coefficient (0.99) in this subgroup was found between the VS05 and VT02 clones, confirming that they originated from one family. The third subgroup of cluster I consisted of HLO5 alone, while the fourth subgroup had 4 clones, including 2 (GB01 and GB02) from Gaofeng and 2 (VSO3 and HL01) from Guangxi. 
Figure 3

Dendogram showing genetic relationships among the 45 blackwood clones obtained using 17 SSR markers generated by UPGMA.

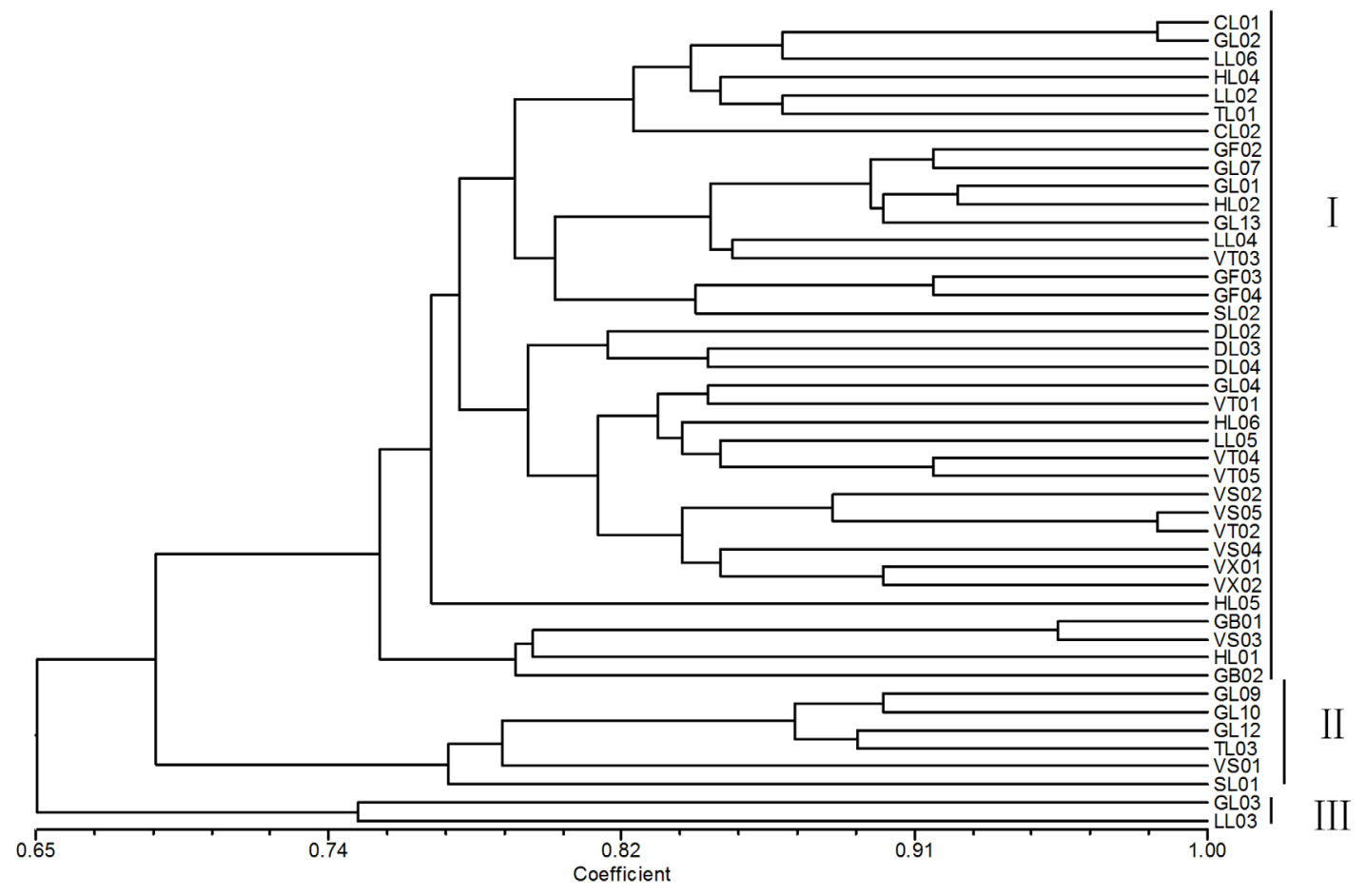

Cluster II comprised 6 clones, with 3 (GL09, GL10 and GL12) from Taishan (Guangdong) and others (TL03, VS01 and SL01). Clones GL09 and GL10 showed a genetic similarity coefficient of 0.90 , and had similarity coefficients of 0.87 and 0.89 with GL12 and TL03, respectively. Cluster III comprised 2 clones only, namely GL03 and LL03, with a similarity coefficient of 0.74 .

Microsatellite data generated in the present study suggested that the blackwood clones sampled in China had a relative narrow genetic base. However, some provenances with good stem form were identified, and could be useful in further breeding assays for single, straight, branch-free stem, and fast growth plants. Therefore, the selected SSR markers generated useful information that will help identify clones to include in future breeding programs.

\section{Acknowledgements}

We would like to thank the Forestry Administration of Guangdong Province for financially supporting this study through the Forestry Technology Innovation Program of Guangdong grant (2014KJCX010).

\section{References}

Aggarwal RK, Allainguillaume J, Bajay M, Barthwal S, Bertolino P, Chauhan P, Consuegra S, Croxford A, Dalton DL, Den Belder E (2011) Permanent genetic resources added to molecular ecology resources database 1 August 201030 September 2010. Molecular ecology resources 11:219-222 Available at https://doi.org/10.1111/j.1755-0998.2010.02944.x Bantte K, Prasanna B (2003) Simple sequence repeat polymorphism in Quality Protein Maize (QPM) lines. Euphytica 129:337-344

Botstein D, White RL, Skolnick M, Davis RW (1980) Construction of a genetic linkage map in man using restriction fragment length polymorphisms. American journal of human genetics 32: $314 p$

Bradbury GJ, Beadle CL, Potts BM (2010) Genetic control in the survival, growth and form of Acacia melanoxylon. New forests 39:139-156 Available at https://doi.org/10.1007/s11056-009-9160-9

Butcher P, Decroocq S, Gray Y, Moran G (2000) Development, inheritance and cross-species amplification of microsatellite markers from Acacia mangium. Theoretical and Applied Genetics 101:1282-1290 Available at https://doi.org/10.1007/s001220051608

Butcher P, Moran G (2000) Genetic linkage mapping in Acacia mangium. 2. Development of an integrated map from two outbred pedigrees using RFLP and microsatellite loci. Theoretical and Applied Genetics 101:594-605 Available at https://doi.org/10.1007/s001220051521

Cowan R, Maslin B (2001) Acacia cyclops. Flora of Australia 11: $138 \mathrm{p}$

Fan L, Zhang M-Y, Liu Q-Z, Li L-T, Song Y, Wang L-F, Zhang S-L, Wu J (2013) Transferability of Newly Developed Pear SSR Markers to Other Rosaceae Species. Plant Molecular Biology Reporter 31: 1271-1282 Available at https://doi.org/10.1007/s11105-013-0586-z

Gao J, He T, Li Q-M (2012) Traditional home-garden conserving genetic diversity: a case study of Acacia pennata in southwest China. Conservation Genetics 13:891-898. Available at https://doi.org/10.1007/s10592-012-0338-x 
Gopal J, Oyama K (2005) Genetic base of Indian potato selections as revealed by pedigree analysis. Euphytica 142:23-31. Available at https://doi. org/10.1007/s10681-005-0448-3

Grewal G, Gill R, Dhillon G, Vikal Y (2014) Molecular characterisation and genetic diversity analysis of Populus deltoides Bartr. ex Marsh. clones using SSR markers. Indian Journal of Biotechnology 13:388-397

Gustafson P, Fredua-Agyeman R, Adamski D, Liao RJ, Morden C, Borthakur D (2008) Development and characterization of microsatellite markers for analysis of population differentiation in the tree legume Acacia koa (Fabaceae: Mimosoideae) in the Hawaiian Islands. Genome 51:1001-1015. Available at https://doi.org/10.1139/g08-087

HU W, CHEN Y, LIN L-s, LIN S-z (2008) The Uniform Design Optimization of ISSRPCR System in Acacia melanoxylon. Journal of Fujian Normal University (Natural Science Edition) 6:020 p

Isoda K, Watanabe A (2006) Development of SSR markers for Acacia mangium Bulletin of the Forest Tree Breeding Center (Japan).

Kato S, Matsumoto A, Yoshimura K, Katsuki T, Iwamoto K, Kawahara T, Mukai Y, Tsuda Y, Ishio S, Nakamura K (2014) Origins of Japanese flowering cherry (Prunus subgenus Cerasus) cultivars revealed using nuclear SSR markers. Tree Genetics \& Genomes 10:477-487. Available at https://doi.org/10.1007/ s11295-014-0697-1

Le S, Ratnam W, Harwood CE, Larcombe MJ, Griffin RA, Koutoulis A, Harbard JL, Cyer KS, Yee LW, Ha TH, Vaillancourt RE (2016) A multiplexed set of microsatellite markers for discriminating Acacia mangium, A. auriculiformis, and their hybrid. Tree Genetics \& Genomes 12:1-10. Available at https://doi. org/10.1007/s11295-016-0990-2

Nagashree B, Santosh Kumar H, Gurumurthy B, Nataraja Karaba N, Shivanna M (2015) PCR-based RAPD technique to determine induced salinity tolerance in vitro in Acacia auriculiformis. Plant Biosystems-An International Journal Dealing with all Aspects of Plant Biology 149:15-23. Available at https:// doi.org/10.1080/11263504.2013.806367

$\mathrm{Ng} \mathrm{CH}$, Koh S, Lee S, Ng K, Mark A, Norwati M, Wickneswari R. (2005) Isolation of 15 polymorphic microsatellite loci in Acacia hybrid (Acacia mangium $\times$ Acacia auriculiformis). Molecular Ecology Notes 5:572-575. Available at https:// doi.org/10.1111/j.1471-8286.2005.00994.x

Nicot N, Chiquet V, Gandon B, Amilhat L, Legeai F, Leroy P, Bernard M, Sourdille P (2004) Study of simple sequence repeat (SSR) markers from wheat expressed sequence tags (ESTs). Theoretical and Applied Genetics 109:800805. Available at https://doi.org/10.1007/s00122-004-1685-x

Peakall R, Smouse PE (2006) GENALEX 6: genetic analysis in Excel. Population genetic software for teaching and research. Molecular Ecology Notes 6:288295. Available at https://doi.org/10.1111/j.1471-8286.2005.01155.x

Pinkard E, Beadle C (2002) Blackwood (Acacia melanoxylon R. Br.) plantation silviculture: a review. Australian Forestry 65:7-13. Available at https://doi.org/ 10.1080/00049158.2002.10674847

Saito Y, Lian C, Ishio S, Ide Y (2014) Isolation and characteration of eight microsatellite markers in Paraserianthes falcataria, a fast-growing tropical leguminous tree species. Journal of Tropical Forest Science:295-297

Selkoe KA, Toonen RJ (2006) Microsatellites for ecologists: a practical guide to using and evaluating microsatellite markers. Ecology letters 9:615-629 Available at https://doi.org/10.1111/j.1461-0248.2006.00889.x

Wang LX, Chen HL, Bai P, Wu JX, Wang SH, Blair MW, Cheng XZ (2015) The transferability and polymorphism of mung bean SSR markers in rice bean germplasm. Molecular Breeding 35:1-10. Available at https://doi.org/10.1007/ s11032-015-0280-y

Wei H (2013) Establishment of cDNA-AFLP Analysis System with Two Low-frequency Restriction Enzyme in Acacia melanoxylon. Journal of Fujian Normal University (Natural Science Edition) 1:019 p.

Wong MM, Cannon CH, Wickneswari R (2012) Development of high-throughput SNP-based genotyping in Acacia auriculiformis $\times$ A. mangium hybrids using short-read transcriptome data. BMC genomics 13:726 $\mathrm{p}$. Available at https://doi.org/10.1186/1471-2164-13-726

Y Saito CL, Ishio S, Ide Y (2014) Isolation and characterisation of eight microsatellite markers in Paraserianthes falcataria, a fast-growing tropical leguminous tree species. Journal of Tropical Forest Science 26:295-297

Yuskianti V, Xiang Z, Shiraishi S (2011) Development of sequence characterised amplified region (SCAR) markers in Acacia auriculiformis. Journal of Tropical Forest Science:299-304

Zhang F, Searle S, Chen Z (2004) Acacia melanoxylon-provenance and family variation in survival, height and stem number at 14 months in Guangdong province China. Blackwood management: learning from New Zealand. RIRDC Publication:63-70

Zhang LY, Bernard M, Leroy P, Feuillet C, Sourdille P (2005) High transferability of bread wheat EST-derived SSRs to other cereals. Theoretical and Applied Genetics 111:677-687. Available at https://doi.org/10.1007/s00122-005-2041-5 